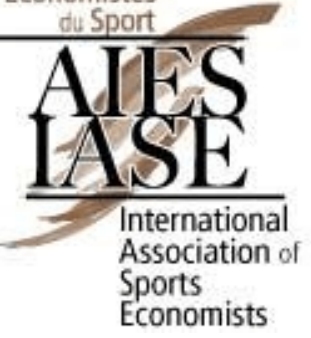

IASE/NAASE Working Paper Series, No. 09-16

\title{
Wage and Employment Effects of the Olympic Games in Atlanta 1996 Reconsidered
}

\author{
Arne Feddersen ${ }^{\dagger}$ and Wolfgang Maennig ${ }^{\dagger \dagger}$
}

November 2009

\begin{abstract}
We estimate the economic effects of the 1996 Atlanta Olympic Games. Our difference in difference model checks for serial correlation and allows for a simultaneous test of level and trend effects, but otherwise follows HOTCHKISS, MOORE, \& ZOBAY (2003) in this journal. We were not able to reconfirm their finding that the Games had significant positive employment effects. We do, however, reaffirm their result of no significant wage effects.
\end{abstract}

JEL Classification Codes: H54, R12, L83

Keywords: Olympic Games, sports economics, mega events

This paper is also available as Hamburg Contemporary Economic Discussions, No. 25.

University of Hamburg, Department of Economics, Chair for Economic Policy, phone: 040 - 42838 - 4628, fax: 040 - 42838 - 6251, feddersen@econ.uni-hamburg.de

University of Hamburg, Chair for Economic Policy, Von-Melle-Park 5, 20146 Hamburg, Germany, E-mail: maennig@econ.uni-hamburg.de, phone: +49 (0)40 42838 - 4622 , fax: $+49(0) 4042838-6251$ 


\title{
Wage and Employment Effects of the Olympic Games in Atlanta 1996 Reconsidered*
}

\begin{abstract}
We estimate the economic effects of the 1996 Atlanta Olympic Games. Our difference in difference model checks for serial correlation and allows for a simultaneous test of level and trend effects, but otherwise follows HOTCHKISS, MOORE, \& ZOBAY (2003) in this journal. We were not able to reconfirm their finding that the Games had significant positive employment effects. We do, however, reaffirm their result of no significant wage effects.
\end{abstract}

Keywords: Olympic Games, sports economics, mega events JEL classification: H54, R12, L83

Version: May 2009

In their SEJ (2003) contribution, HOTCHKISS, MOORE, \& ZOBAY (HMZ) found significant positive employment effects of a major sporting event, namely, the 1996 Olympic Games in Atlanta. Their contribution is notable because it is one of the very few multivariate ex-post studies that found such positive effects. Their estimate that roughly 293,000 additional jobs resulted from the Olympic Games exceeds by a wide margin BAADE \& MATHESON's (2002) ex post estimate of employment gains for the same event that ranged from 3,500 to 42,500 added jobs and even the usually optimistic projections of the Olympic organizers. ${ }^{1}$

Two papers that were published after $\mathrm{HMZ}$ have raised concerns associated with their analysis. (1) In another research context, BERTRAND, DUFLO, \& MULLAINATHAN (2004) pointed out that DD models tend to overestimate the significance of an intervention in the case of serial correlation. HMZ did not address a potential

\footnotetext{
* We thank Julie Hotchkiss, Robert Baade, Dennis Coates, Brad Humphreys, and Victor Matheson for valuable comments.

1 Cf. MATHESON (2006) for an overview.
} 
serial correlation problem. (2) HMZ modeled the intervention effect in two separate DD models, one to test for an intercept (or level) effect and a second to test for a slope (trend) effect. Also in another research context, GALSTER, TATIAN, \& PETTIT (2004) argued that a standard DD approach may yield distorted results if level and trend effects are not estimated together.

We reconsider the effects of the 1996 Atlanta Olympic Games by taking into account the two caveats but otherwise following the exact setup of HMZ; e.g., we use the same time span (the first quarter of 1985 until the third quarter of 2000), convert nominal (per worker) wages as $\mathrm{HMZ}$ did, use the same industry mix, and follow an endogenous method to determine the "true" point in time of the intervention. ${ }^{2}$ We gratefully acknowledge Julie L. Hotchkiss, Robert E. Moore, and Stephanie M. Zobay for providing the original aggregated data and the SAS code.

Our estimation model accounts for both changes in the intercept and changes in the slope:

$$
\begin{gathered}
\ln Z_{i t}=\gamma_{1} X_{i}+\gamma_{2} V N V_{i}+\gamma_{3} \text { POST }_{t}+\gamma_{4} V N V_{i} \cdot \text { POST }_{t}+\gamma_{5} \text { trend }+ \\
\gamma_{6} \text { trend } \cdot V N V_{i}+\gamma_{7} \text { trend } \cdot \operatorname{POST}_{t}+\gamma_{8} \text { trend } \cdot V N V_{i} \cdot P O S T_{t}+\varepsilon_{i t}
\end{gathered}
$$

where $Z_{i t}$ is log employment or log average real monthly wage per worker in county $i$ of Georgia in quarter $t$, respectively. $X_{i}$ is a vector of covariates (for the industry mix, displayed by the employee shares of industry classes, and the population) of each county. As these variables should cover observable differences in the basic endowments of the counties, they are fixed to the values in the year 1990. POST $_{t}$ is the intervention variable for all counties. It takes a value of zero before the intervention and a value of one following the intervention. The variable $V N V_{i}$ controls for permanent level differences between the treatment group (venue/near-venue counties) and the control group (non-venue counties). The variable takes a value of one if a county is a venue or near-venue county and zero

2 The models were first estimated with POST $_{t}$ being equal to one for each of the years from 1991 to 1998 . In concurrence with $\mathrm{HMZ}$, the model with the best F statistic was chosen. 
otherwise. $V N V_{i} \cdot P O S T_{t}$ is an interacted variable and takes a value of one for the post-intervention period for the treatment group. It should capture an additional level shift only if it affects the treatment group. trend is a time trend starting with a value of 85 in the year 1985 and increasing by 0.25 each quarter. This variable captures an overall trend for all counties in Georgia.

The variable trend $V N V_{i}$ isolates a difference in the trend of the treatment group for the whole time period, while trend $\cdot \mathrm{POST}_{t}$ indicates changes in the trend for all counties in the aftermath of the intervention. Finally, the model contains an interacted term for trend differences for the treatment group during the post period (trend $\cdot V N V_{i} \cdot P O S T_{t}$ ). $\gamma_{1}$ to $\gamma_{8}$ are coefficients to be estimated. Positive economic effects of the Olympic Games should lead to significance for at least one of the coefficients $\gamma_{4}$ and $\gamma_{8}$. In the original HMZ level (trend) model, $\gamma_{5}=\gamma_{6}=\gamma_{7}=\gamma_{8}$ $=0\left(\gamma_{2}=\gamma_{3}=\gamma_{4}=0\right)$. By allowing for the possibility of a simultaneous adjustment of the intercept and the slope, our model may reduce the amount of randomness in the way the model fits into the real development of employment or wages. Table 1 reports the Wooldridge test for serial correlation within the panel context and the corresponding $\mathrm{F}$ statistic. For the employment regression, no problems with serial correlation arise, while in the case of the wage model, they do. To address this issue, we follow BERTRAND, DUFLO, \& MULLAINATHAN (2004), who suggest an arbitrary variance-covariance matrix, which is consistent in the presence of any correlation pattern within cross-sections over time. This procedure adjusts the standard error for clusters in the cross-sections of the panel, but it does not affect the coefficients.

Table 1 indicates that with these specifications, the existence of a positive Olympic effect is not clear anymore. The coefficients of the variables particular interest $\left(V N V_{i} \cdot P O S T_{t}\right.$ and trend $\left.\cdot V N V_{i} \cdot P O S T_{t}\right)$ are not significant at the conventional $1 \%$ or $5 \%$ error levels, neither for employment or for wages. Only at a $10 \%$ level are the two coefficients for the employment estimation significant, although one has to bear in mind that the (weakly significant) positive treatment trend for the post period is combined with a (weakly significant) substantial negative level effect. While care must be taken in placing too much weight on coefficients that are not 
statistically significant, these results suggest that, given the magnitudes of the VNV $x$ POST and trend $x$ VNV $x$ POST coefficients in the employment equation, the positive trend effect will only catch the negative level effect after $\left(1.1036 / 0.0115^{*} 0.25=\right) 384$ quarters, i.e. in 96 years. That is hardly the sort of "benefit" of hosting the Olympics that would motivate most cities to pursue hosting the event.

In light of these findings, the economic effects of the 1996 Atlanta Olympic Games are in line with almost all other scholarly ex-post analysis of mega sporting events that do not find positive economic effects. 
Tab. 1 DD in the Intercept and in the Slope

\begin{tabular}{|c|c|c|}
\hline & In Employment & In Real Wages \\
\hline Intercept & $\begin{array}{l}-3.47422^{* * *} \\
(0.5831)\end{array}$ & $\begin{array}{l}5.5022 \text { *** } \\
(1.7227)\end{array}$ \\
\hline$\%$ Agriculture & $\begin{array}{l}0.5929^{* * *} \\
(0.1262)\end{array}$ & $\begin{array}{l}-1.4728 \\
(0.9554)\end{array}$ \\
\hline$\%$ Mining & $\begin{array}{l}-1.1569^{* * *} \\
(0.3374)\end{array}$ & $\begin{array}{l}-0.6229 \\
(4.3612)\end{array}$ \\
\hline$\%$ Construction & $\begin{array}{l}-4.4234^{* * *} \\
(0.1542)\end{array}$ & $\begin{array}{l}-2.1008^{* *} \\
(0.9393)\end{array}$ \\
\hline$\%$ Manufacturing & $\begin{array}{l}2.5280^{* * *} \\
(0.0968)\end{array}$ & $\begin{array}{c}1.3655^{*} \\
(0.7920)\end{array}$ \\
\hline$\%$ Transportation, communication, and utilities & $\begin{array}{l}0.5612^{* * *} \\
(0.1185)\end{array}$ & $\begin{array}{l}-0.5757 \\
(0.7242)\end{array}$ \\
\hline$\%$ Retail & $\begin{array}{l}1.9587^{* * *} \\
(0.1328)\end{array}$ & $\begin{array}{l}-2.3729^{* *} \\
(1.0650)\end{array}$ \\
\hline \% Financial, insurance, and real estate & $\begin{array}{l}2.9330^{* * *} \\
(0.1856)\end{array}$ & $\begin{array}{l}3.0767^{* *} \\
(1.5425)\end{array}$ \\
\hline \% Public administration & $\begin{array}{l}-3.2915^{* * *} \\
(0.1226)\end{array}$ & $\begin{array}{l}-3.0517^{* * *} \\
(0.9227)\end{array}$ \\
\hline In (population 1990) & $\begin{array}{l}1.0333^{* * *} \\
(0.0584)\end{array}$ & $\begin{array}{c}0.2156 \\
(0.1442)\end{array}$ \\
\hline trend $\times \ln$ (population 1990) & $\begin{array}{c}0.0005 \\
(0.0006)\end{array}$ & $\begin{array}{l}-0.0025^{*} \\
(0.0015)\end{array}$ \\
\hline Quarter 2 & $\begin{array}{l}0.0242^{* * *} \\
(0.0076)\end{array}$ & $\begin{array}{l}0.1789^{* * *} \\
(0.0117)\end{array}$ \\
\hline Quarter 3 & $\begin{array}{c}0.0169 \text { ** } \\
(0.0076)\end{array}$ & $\begin{array}{c}0.1981 \\
(0.0135)\end{array}$ \\
\hline Quarter 4 & $\begin{array}{l}0.0232^{* * *} \\
(0.0078)\end{array}$ & $\begin{array}{c}0.2711^{* * *} \\
(0.0138)\end{array}$ \\
\hline
\end{tabular}




\begin{tabular}{|c|c|c|}
\hline VNV & $\begin{array}{l}-2.03211^{* * *} \\
(0.2950)\end{array}$ & $\begin{array}{l}-1.2231^{* *} \\
(0.5250)\end{array}$ \\
\hline POST & $\begin{array}{c}0.1344 \\
(0.2778)\end{array}$ & $\begin{array}{l}-3.3996^{* * *} \\
(0.4452)\end{array}$ \\
\hline VNV $\times$ POST & $\begin{array}{l}-1.1036 * \\
(0.5606)\end{array}$ & $\begin{array}{c}0.1760 \\
(0.6576)\end{array}$ \\
\hline Trend & $\begin{array}{l}0.01222^{* *} \\
(0.0062)\end{array}$ & $\begin{array}{c}0.0270 \\
(0.0172)\end{array}$ \\
\hline trend $\times$ POST & $\begin{array}{l}-0.0009 \\
(0.0029)\end{array}$ & $\begin{array}{l}0.0377^{* * *} \\
(0.0049)\end{array}$ \\
\hline trend $\times$ VNV & $\begin{array}{l}0.0199^{* * *} \\
(0.0033)\end{array}$ & $\begin{array}{l}0.0133^{* *} \\
(0.0060)\end{array}$ \\
\hline trend $\times \mathrm{VNV} \times$ POST & $\begin{array}{c}0.0115^{*} \\
(0.0059)\end{array}$ & $\begin{array}{l}-0.0019 \\
(0.0073)\end{array}$ \\
\hline $\mathrm{R}^{2}$ & 0.96 & 0.56 \\
\hline $\operatorname{adj} . R^{2}$ & 0.96 & - \\
\hline Wooldridge & 2.59 & 14.34 \\
\hline adj. Std. Err. & no & yes \\
\hline Intervention & 1994 & 1991 \\
\hline F statistic & 12,356 & 149 \\
\hline $\mathrm{N}$ & 10,017 & 10,017 \\
\hline
\end{tabular}

Notes: ${ }^{*}$ denotes significance at the $1 \%$ level. ${ }^{* *}$ denotes significance at the $5 \%$ level. ${ }^{* * *}$ denotes significance at the $1 \%$ level. The excluded industry category is service. Standard errors are in parentheses. If indicated, standard errors are computed using an arbitrary variance-covariance matrix as suggested by BERTRAND, DUFLO, \& MULLAINATHAN (2004, pp. 270-272). 


\section{Literature}

BAADE, R. A., \& MATHESON, V. A. (2002). Bidding for the Olympics: Fool's Gold? In C. P. BARROS, M. IBRAHIMO \& S. SZYMANSKI (Eds.), Transatlantic Sport: The Comparative Economics of North American and European Sports (pp. 127-151). London: Edward Elgar Publishing.

BERTRAND, M., DUFLO, E., \& MULLAINATHAN, S. (2004). How Much Should We Trust Differences-in-Differences Estimates? Quarterly Journal of Economics, 119(1), 249-275.

GALSTER, G., TATIAN, P., \& PETTIT, K. (2004). Supportive Housing and Neighborhood Property Value Externalities. Land Economics, 80(1), 33-54.

HOTCHKISS, J. L., MOORE, R. E., \& ZOBAY, S. M. (2003). Impact of the 1996 Summer Olympic Games on Employment and Wages in Georgia. Southern Economic Journal, 69(3), 691-704.

MATHESON, V. (2006). Mega-Events: The Effect of the World's Biggest Sporting Events on Local, Regional, and National Economies, Working Paper NO. 60-10. Worcester, MA: Department of Economics, College of the Holy Cross. 